\title{
A!
}

This is an electronic reprint of the original article.

This reprint may differ from the original in pagination and typographic detail.

Koskinen, Ari M.P.; Oila, Markku J.; Tois, Jan E.

\section{Synthesis of a novel carboxy functionalized PyOX-ligand}

Published in:

Tetrahedron Letters

DOI:

10.1016/j.tetlet.2004.12.045

Published: 01/01/2005

Document Version

Publisher's PDF, also known as Version of record

Please cite the original version:

Koskinen, A. M. P., Oila, M. J., \& Tois, J. E. (2005). Synthesis of a novel carboxy functionalized PyOX-ligand.

Tetrahedron Letters, (46), 967-969. https://doi.org/10.1016/j.tetlet.2004.12.045

This material is protected by copyright and other intellectual property rights, and duplication or sale of all or part of any of the repository collections is not permitted, except that material may be duplicated by you for your research use or educational purposes in electronic or print form. You must obtain permission for any other use. Electronic or print copies may not be offered, whether for sale or otherwise to anyone who is not an authorised user. 
Markku J. Oila, Jan E. Tois, and Ari M. P. Koskinen. 2005. Synthesis of a novel carboxy functionalized PyOX-ligand. Tetrahedron Letters, volume 46, pages 967-969.

(C) 2005 Elsevier Science

Reprinted with permission from Elsevier. 


\title{
Synthesis of a novel carboxy functionalized PyOX-ligand
}

\author{
Markku J. Oila, Jan E. Tois and Ari M. P. Koskinen* \\ Laboratory of Organic Chemistry, Helsinki University of Technology, PO Box 6100, FIN-02015 HUT, Finland
}

Received 29 October 2004; revised 29 November 2004; accepted 8 December 2004

\begin{abstract}
A short and convenient synthesis of a carboxy functionalized PyOX-core is presented. The carboxy functionality offers a wide variety of possibilities for further modification. In this paper, the core is functionalized with a mercapto tail.

(c) 2004 Elsevier Ltd. All rights reserved.
\end{abstract}

In the late $1980 \mathrm{~s}$, non- $C_{2}$-symmetric oxazoline ligands and especially the 2-(2'-pyridyl)oxazolines (PyOX) were shown to be excellent ligands in asymmetric synthesis. Chiral PyOX-ligands have been used in, e.g. hydrosilylation ${ }^{1}$ and Michael reactions. ${ }^{2}$ In the late $1990 \mathrm{~s}, C_{1}$-symmetric PyOX was also found to be an outstanding ligand in Pdcatalyzed allylic alkylation reactions, ${ }^{3}$ being superior to the $C_{2}$-symmetric ligands (e.g. PyBOX) due to it's ability to form two different palladium complexes. ${ }^{3 a}$ The metal complex forming ability of the PyOX-core also confers biological activity, e.g. as iron chelators. ${ }^{4}$

We present herein a new and convenient method to construct PyOX-ligands substituted with functionalities suitable for further conversion, e.g. to nanomaterials. Our approach is based on amido alcohol formation, mesylation and base-assisted cyclization. To our knowledge, this general method has only been tried by Meyers, ${ }^{5}$ using long reaction times. In our hands, the cyclization in this one-pot protocol required very long reaction times and prolonged heating to complete, which led to dark coloured reaction mixtures, as also observed by Wuts. ${ }^{6}$ PyOX-ligands have usually been prepared by longer synthetic routes from 2-pyridyl nitriles by heating with an amino alcohol in a solvent with a metal salt catalyst like $\mathrm{ZnCl}_{2},{ }^{7 \mathrm{a}} \mathrm{CuCl}_{2}{ }^{7 \mathrm{~b}}$ or $\mathrm{Cd}(\mathrm{OAc})_{2} \cdot{ }^{7 \mathrm{c}}$ Another common route to the PyOX-core involves imidate formation ${ }^{8}$ and further reaction with the desired amino alcohol.

\footnotetext{
Keywords: PyOX-ligand; Cyclization; Mesylate; Amido alcohol; DBU; Oxazoline.

* Corresponding author. Tel.: +358 9451 2526; fax: +358 9451 2538; e-mail: ari.koskinen@hut.fi
}

Amido alcohol 5 was constructed from L-phenylalaninol $\mathbf{4}$ and pyridine-2,5-dicarboxylic acid $\mathbf{1}$ as follows. Exhaustive esterification of $\mathbf{1}$, followed by selective hydrolysis of the more electrophilic ${ }^{9}$ ester at the 2-position of the diester 2 gave the monoacid $\mathbf{3}$. The acid was then converted to the corresponding acid chloride and reacted with amino alcohol 4 . In the case of 2-pyridyl acids, the coupling is very selective using equimolar amounts of amino alcohol and acid and no ester byproducts were observed after recrystallization. This was, however, not the case when the corresponding benzoic acids were used. ${ }^{10}($ Scheme 1$)$

Cyclization of $\mathbf{5}$ was performed in two steps for three reasons: ease of purification, reaction efficiency and ease of reaction monitoring. The similar polarity of amido alcohol 5 and oxazoline 7 makes monitoring on TLC very difficult. The formation and disappearance of mesylate 6, however, were easily followed by TLC. Mesylation of $\mathbf{5}$ proceeded very fast using DMAP as catalyst at room temperature, total conversion was always reached within $15 \mathrm{~min}$. The mesylate $\mathbf{6}$ is stable to aqueous extractions and silica and it was isolated by a simple extraction and recrystallization. It was converted to the PyOX-adduct 7 using DBU as the base. ${ }^{6}$ No byproducts were observed in this step, either. It has been reported that base treatment could also yield two byproducts: the aziridinyl or the vinylic amide. The aziridinyl amide was formed selectively, if Mitsunobu conditions were used. ${ }^{11 \mathrm{a}}$ The use of $t$-BuOK as the base has been reported to yield the aziridinyl amide and the corresponding vinyl amide as products, but no oxazoline formation. ${ }^{11 \mathrm{~b}}$ Stoichiometric amounts of base used in the final hydrolysis facilitated the hydrolysis of 7 without decomposition of the PyOX-core, yielding the key intermediate $\mathbf{8} .{ }^{12}$ (Scheme 2) 
<smiles>O=C(O)c1ccc(C(=O)O)nc1</smiles>

1<smiles>CC#CC</smiles>

2<smiles>COC(=O)c1ccc(C(=O)O)nc1</smiles>

3

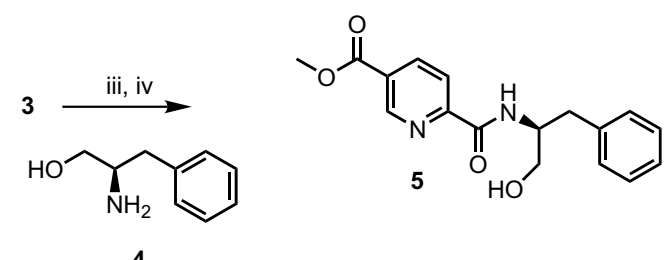

Scheme 1. Reagents and conditions: (i) $\mathrm{MeOH}, \mathrm{H}_{2} \mathrm{SO}_{4}$, reflux, 17.5 h, $91 \%$; (ii) $\mathrm{NaOH}, \mathrm{MeOH}$, reflux, $2.5 \mathrm{~h}, 90 \%$; (iii) $\mathrm{SOCl}_{2}$, reflux, 3 h; (iv) 4, NEt 3 , $\mathrm{CH}_{2} \mathrm{Cl}_{2}, \mathrm{rt}, 30 \mathrm{~min}, 64 \%$.<smiles>CC#CCCCCC(C)C(C)C(=O)c1ccc(C(=O)N[C@@H](COC)Cc2ccccc2)cn1</smiles>

Scheme 2. Reagents and conditions: (i) $\mathrm{MsCl}, \mathrm{NEt}_{3}, \mathrm{DMAP}, \mathrm{CH}_{2} \mathrm{Cl}_{2}, \mathrm{rt}, 3 \mathrm{~min}, 92 \%$; (ii) $\mathrm{DBU}, \mathrm{THF}, 50{ }^{\circ} \mathrm{C}, 8 \mathrm{~h}, 84 \%$; (iii) $\mathrm{NaOH}$, aq $\mathrm{MeOH}$, reflux, $4 \mathrm{~h}, 71 \%$

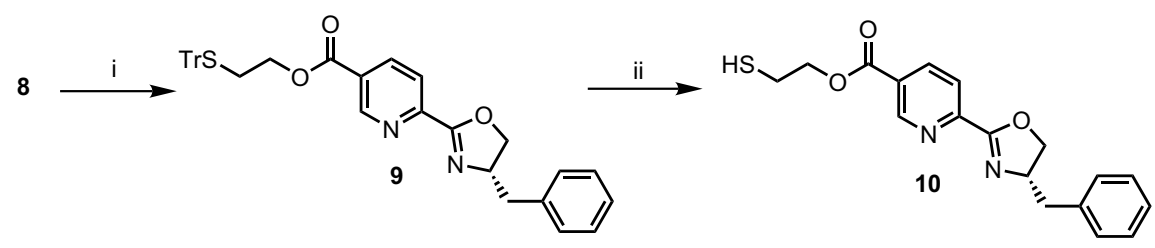

Scheme 3. Reagents and conditions: (i) (a) DIC, $\mathrm{CH}_{2} \mathrm{Cl}_{2}, \mathrm{DMF}$; (b) $\mathrm{TrSCH}_{2} \mathrm{CH}_{2} \mathrm{OH}, \mathrm{DMAP}, \mathrm{CH}_{2} \mathrm{Cl}_{2}, \mathrm{rt}, 22 \mathrm{~h}, 72 \%$; (ii) TFA, Et 3 SiH, $\mathrm{CH}_{2} \mathrm{Cl}$, rt, $10 \mathrm{~min}, 91 \%$.

To prove the versatility of the carboxy functionality in $\mathbf{8}$, a mercapto tail was attached to the acid. The tail, $S$-tritylmercaptoethanol, ${ }^{13}$ was coupled with the acid using a standard procedure (Scheme 3) to form the protected mercapto ester 9. Deprotection of the thiol using TFA with triethylsilane as scavenger yielded the target molecule 10. ${ }^{14}$

A novel key intermediate 8 for the preparation of PyOX-ligands was prepared using a new and simple protocol. Reaction steps were optimized to be clean and moderately to very fast. The first application of intermediate $\mathbf{8}$ is the mercapto ester $\mathbf{1 0}$, which has a mercapto terminus for attachment to materials such as gold $^{15 a-c}$ or functionalized glass ${ }^{15 \mathrm{c}, \mathrm{d}}$ in various applications. ${ }^{16}$
This is of great interest for catalyst development and is under investigation in our laboratory and results will be presented in the near future.

\section{Acknowledgements}

Financial support from the Finnish National Technology Agency, TEKES, is gratefully acknowledged.

\section{References and notes}

1. (a) Brunner, H.; Obermann, U. Chem. Ber. 1989, 122, 499-507; (b) Brunner, H.; Brandl, P. J. Organomet. Chem. 
1990, 390, C81-C83; (c) Balavoine, G.; Clinet, J. C.; Lellouche, I. Tetrahedron Lett. 1989, 30, 5141-5144.

2. Christoffers, J.; Mann, A.; Pickardt, J. Tetrahedron 1999, $55,5377-5388$.

3. (a) Nordström, K.; Macedo, E.; Moberg, C. J. Org. Chem. 1997, 62, 1604-1609; (b) Bremberg, U.; Larhed, M. Moberg, C.; Hallberg, A. J. Org. Chem. 1999, 64, 10821084; (c) Chelucci, G.; Medici, S.; Saba, A. Tetrahedron: Asymmetry 1999, 10, 543-550; (d) Chelucci, G.; Deriu, S.; Saba, A.; Valenti, R. Tetrahedron: Asymmetry 1999, 10, 1457-1464.

4. Bergeron, R. J.; Wiegand, J.; Dionis, J. B.; Egli-Karmakka, M.; Frei, J.; Huxley-Tencer, A.; Peter, H. H. J. Med. Chem. 1991, 34, 2072-2078.

5. Meyers, A. I.; Robichaud, A. J.; McKennon, M. J. Tetrahedron Lett. 1992, 33, 1181-1184.

6. Wuts, P. G. M.; Northuis, J. M.; Kwan, T. A. J. Org. Chem. 2000, 65, 9223-9225.

7. (a) Bolm, C.; Veickhardt, K.; Zehnder, M.; Ranff, T. Chem. Ber. 1991, 124, 1173-1180; (b) Breslow, R.; Schmir, M. J. Am. Chem. Soc. 1971, 93, 4960-4961; (c) Aggarwal, V. K.; Bell, L.; Coogan, M. P.; Jubault, P. J. Chem. Soc., Perkin Trans. 1 1998, 2037-2042.

8. Schaefer, F. C.; Peters, G. A. J. Org. Chem. 1961, 26, 412418.

9. Faul, M. M.; Ratz, A. M.; Sullivan, K. A.; Trankle, W. G.; Winneroski, L. L. J. Org. Chem. 2001, 66, 5772-5782.

10. Oila, M. J., unpublished results.

11. (a) Wipf, P.; Miller, C. P. Tetrahedron Lett. 1992, 33, 6267-6270; (b) Krook, M. A.; Miller, M. J. J. Org. Chem. 1985, 50, 1126-1128.

12. Data for compound 8: $R_{\mathrm{f}}=0 \quad(67 \%$, EtOAc/hexane); $\mathrm{mp}=136-137{ }^{\circ} \mathrm{C} ;[\alpha]_{\mathrm{D}}^{24}+22.0(c 0.5, \mathrm{MeOH}) ;{ }^{1} \mathrm{H} \mathrm{NMR}$ $\delta_{\mathrm{H}} \quad\left(400 \mathrm{MHz}, \quad \mathrm{DMSO}-d_{6}\right) \quad 9.10 \quad\left(\mathrm{dd}, \quad J_{1}=0.8 \mathrm{~Hz}\right.$,
$\left.J_{2}=2.1 \mathrm{~Hz}, 1 \mathrm{H}\right), 8.36\left(\mathrm{dd}, J_{1}=2.1 \mathrm{~Hz}, J_{2}=8.2 \mathrm{~Hz}, 1 \mathrm{H}\right)$, $8.10\left(\mathrm{dd}, J_{1}=0.8 \mathrm{~Hz}, J_{2}=8.2 \mathrm{~Hz}, 1 \mathrm{H}\right), 7.32-7.19(\mathrm{~m}, 5 \mathrm{H})$, $4.64(\mathrm{~m}, 1 \mathrm{H}), 4.49\left(\mathrm{dd}, J_{1}=8.4 \mathrm{~Hz}, J_{2}=9.2 \mathrm{~Hz}, 1 \mathrm{H}\right), 4.16$ $\left(\mathrm{dd}, J_{1}=8.1 \mathrm{~Hz}, J_{2}=8.2 \mathrm{~Hz}, 1 \mathrm{H}\right), 3.01\left(\mathrm{dd}, J_{1}=6.4 \mathrm{~Hz}\right.$, $\left.J_{2}=13.7 \mathrm{~Hz}, 1 \mathrm{H}\right), 2.84\left(\mathrm{dd}, J_{1}=7.1 \mathrm{~Hz}, J_{2}=13.7 \mathrm{~Hz}\right.$, $1 \mathrm{H}) ;{ }^{13} \mathrm{C}$ NMR: $\delta_{\mathrm{C}}\left(100 \mathrm{MHz}, \mathrm{DMSO}-d_{6}\right) 165.8,161.8$, $150.1,149.2,138.0,137.8,129.3,129.1,128.2,126.3,123.7$, $71.9,67.4,62.2,52.7,40.8$. EI-HRMS $\mathrm{m} / \mathrm{z}$ calcd for $\mathrm{C}_{16} \mathrm{H}_{14} \mathrm{~N}_{2} \mathrm{O}_{3}+\mathrm{Na}$ : 305.0902; found: $305.0912(\mathrm{M}+\mathrm{Na})$.

13. Maltese, M. J. Org. Chem. 2001, 66, 7615-7625.

14. Data for compound 10: $R_{\mathrm{f}}=0.23(50 \%$, EtOAc/hexane), $\left.\mathrm{mp}=108.5-109^{\circ} \mathrm{C} ; \quad[\alpha]_{\mathrm{D}}^{24}-25.6(c) 0.5, \mathrm{CH}_{2} \mathrm{Cl}_{2}\right) ;{ }^{1} \mathrm{H}$ $\mathrm{NMR} \quad \delta_{\mathrm{H}}\left(400 \mathrm{MHz}, \mathrm{CDCl}_{3}\right) 9.29\left(\mathrm{dd}, J_{1}=0.5 \mathrm{~Hz}\right.$, $\left.J_{2}=2.0 \mathrm{~Hz}, 1 \mathrm{H}\right), 8.39\left(\mathrm{dd}, J_{1}=2.1 \mathrm{~Hz}, J_{2}=8.2 \mathrm{~Hz}, 1 \mathrm{H}\right)$, $8.14\left(\mathrm{dd}, J_{1}=0.7 \mathrm{~Hz}, J_{2}=8.2 \mathrm{~Hz}, 1 \mathrm{H}\right), 7.33-7.23(\mathrm{~m}, 5 \mathrm{H})$, $4.70(\mathrm{~m}, 1 \mathrm{H}), 4.50(\mathrm{t}, J=6.7 \mathrm{~Hz}, 2 \mathrm{H}), 4.48(\mathrm{dd}$, $\left.J_{1}=9.1 \mathrm{~Hz}, \quad J_{2}=9.2 \mathrm{~Hz}, 1 \mathrm{H}\right), 4.26\left(\mathrm{dd}, J_{1}=7.9 \mathrm{~Hz}\right.$, $\left.J_{2}=8.4 \mathrm{~Hz}, 1 \mathrm{H}\right), 3.30\left(\mathrm{dd}, J_{1}=5.1 \mathrm{~Hz}, J_{2}=13.7 \mathrm{~Hz}\right.$, $1 \mathrm{H}), 2.92\left(\mathrm{td}, J_{1}=6.7 \mathrm{~Hz}, J_{2}=8.4 \mathrm{~Hz}, 2 \mathrm{H}\right), 2.80(\mathrm{dd}$, $\left.J_{1}=9.0 \mathrm{~Hz}, J_{2}=13.9 \mathrm{~Hz}, 1 \mathrm{H}\right), 1.54(\mathrm{t}, J=8.6 \mathrm{~Hz}, 1 \mathrm{H})$; ${ }^{13} \mathrm{C}$ NMR: $\delta_{\mathrm{C}}\left(100 \mathrm{MHz}, \mathrm{CDCl}_{3}\right) 164.3,162.5,150.8$, $150.2,137.8,137.5,129.2,128.6,127.1,126.7,123.6,72.7$, $68.3,66.7,41.5,23.2 ;$ EI-HRMS $\mathrm{m} / \mathrm{z}$ calcd for $\mathrm{C}_{18} \mathrm{H}_{18} \mathrm{~N}_{2} \mathrm{O}_{3} \mathrm{~S}+\mathrm{Na}$ : 365.0936; found: $365.0944(\mathrm{M}+\mathrm{Na})$.

15. (a) Nuzzo, R. G.; Allara, D. L. J. Am. Chem. Soc. 1983, 105, 4481-4483; (b) David, M. O.; Gerriet, T.; Nardin, M.; Schultz, J. Langmuir 2000, 16, 7346-7350; (c) Thomas, K. G.; Kamat, P. V. Acc. Chem. Res. 2003, 36, 888-898; (d) MacBeath, G.; Koehler, A. N.; Schreiber, S. L. J. Am. Chem. Soc. 1999, 121, 7967-7968; (e) Jung, H.; Kulkarni, R.; Collier, C. P. J. Am. Chem. Soc. 2003, 125, 1209612097.

16. Ciszek, J. W.; Stewart, M. P.; Tour, J. M. J. Am. Chem. Soc. 2004, 126, 13172-13173, and references cited therein. 